\title{
Onsite Graywater Treatment in a Two-Stage Electro-Peroxone Reactor with a Partial Recycle of Treated Effluent
}

\author{
Léopold Dobelle, Seungkyeum Kim, Axl X. LeVan, Hugo Leandri, Michael R. Hoffmann, \\ and Clément A. Cid*
}

Cite This: ACS EST Engg. 2021, 1, 1659-1667

Read Online

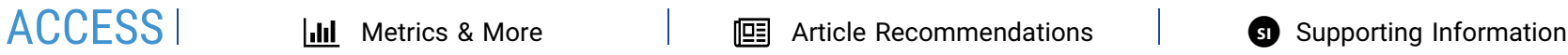

ABSTRACT: The efficacy of an uncoupled electro-peroxone (Eperoxone) prototype reactor system for the treatment of synthetic graywater is determined. The two-stage E-peroxone process integrates ozonation with the in situ production of hydrogen peroxide $\left(\mathrm{H}_{2} \mathrm{O}_{2}\right)$ in a first stage reactor before ozone $\left(\mathrm{O}_{3}\right)$ is converted via the peroxone reaction to a hydroxyl radical $\left(\bullet^{\bullet} \mathrm{OH}\right)$. The two-stage prototype reactor system allows for the generation of $\mathrm{H}_{2} \mathrm{O}_{2}$ via cathodic oxygen reduction in the first-stage reactor before mixing with $\mathrm{O}_{3}$ in the second-stage reactor. This approach prevents the degradation of polytetrafluoroethylene (PTFE) coated carbon cathodes by ${ }^{\bullet} \mathrm{OH}$ that takes place in a single well-mixed reactor that combines electrochemical peroxide generation with $\mathrm{O}_{3}$. The dosage of $\mathrm{H}_{2} \mathrm{O}_{2}$ into the second-stage reactor is optimized to enhance

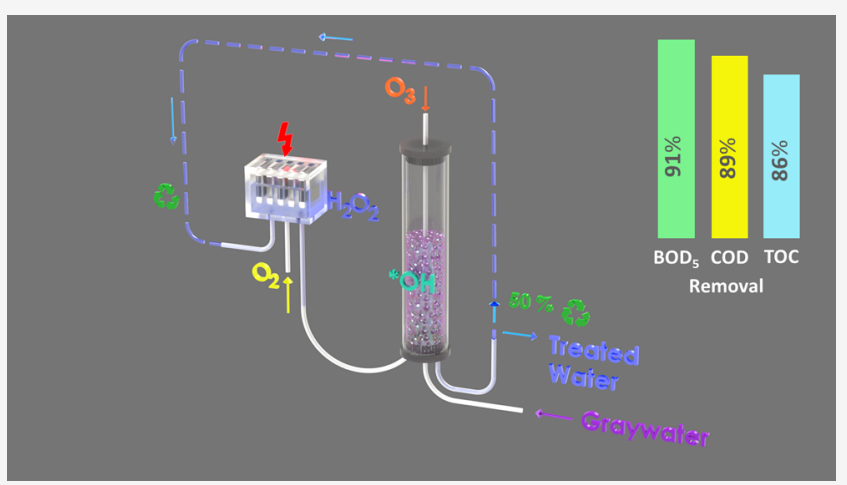
graywater treatment. Under these conditions, the uncoupled E-peroxone system is capable of treating synthetic graywater with an initial chemical oxygen demand $\left(\mathrm{COD}_{0}\right)$ of $358 \mathrm{mg} \mathrm{O} / \mathrm{L}$, a total organic carbon $\left(\mathrm{TOC}_{0}\right)$ of $96.9 \mathrm{mg} / \mathrm{L}$, a biochemical oxygen demand $\left(\mathrm{BOD}_{0}\right)$ of $162 \mathrm{mg} \mathrm{O} / \mathrm{L}$, and a turbidity of $11.2 \mathrm{NTU}$. The two-stage electro-peroxone system can reduce the initial COD by $89 \%$, the $\mathrm{TOC}_{0}$ by $91 \%, \mathrm{BOD}_{0}$ by $86 \%$, and the turbidity by $95 \%$ after 90 min of treatment. At this performance level, the reactor effluent is acceptable for discharge and for use in nonpotable applications such as toilet-water flushing. A portion of the effluent is recycled back into the first-stage reactor to minimize water consumption. Recycling can be repeated consecutively for four or more cycles, although the time required to achieve the desired $\mathrm{H}_{2} \mathrm{O}_{2}$ concentration increased slightly from one cycle to another. The twostage E-peroxone system is shown to be potentially useful for onsite or decentralized graywater treatment suitable for arid watersensitive areas.

KEYWORDS: electro-peroxone, graywater recycling, ozone, hydrogen peroxide

\section{INTRODUCTION}

Climate change has increased water scarcity in many parts of the world, leading to the need for development of new practices for water supply management. ${ }^{1,2}$ Onsite water reuse is one of the key opportunities to increase water supply without a detrimental impact on the environment. ${ }^{3}$ Important steps in this direction have been taken through the development of nonsewered sanitation systems with low- or near-zero water consumption competing with large scale wastewater treatment plants. $^{4,5}$ A complementary approach is the treatment and reuse of graywater. This new paradigm provides a steady water supply that is not influenced by seasonal availability or need. ${ }^{6}$ Furthermore, the level of desired treatment can range from treating graywater for reuse in low contact systems (e.g., as flushing water) or as a first-step treatment to convert processed water into potable water., ${ }^{1,2}$

In order to achieve a high level of water quality for reuse as described in the recommended NSF 350 standard, ${ }^{7}$ graywater treatment systems often employ the same processes as used in large-scale wastewater treatment plants. In general, the treatment train starts either with primary sedimentation or multimedia filtration; these steps are then followed by fixedbed biological treatment and chemical disinfection. ${ }^{8}$ Even though this approach has proven to be effective, the biological treatment requires a residence time ranging from 5 to $24 \mathrm{~h}^{9}$ in a large-volume bioreactor. Advanced graywater treatment systems capable of reducing the organic load and disinfecting the product water without biological treatment may allow for a much smaller size for a household graywater recycling system.

Advanced oxidation processes (AOPs) primarily rely on in situ generation of a hydroxyl radical $\left({ }^{\circ} \mathrm{OH}\right)$ as the primary

Received: June 30, 2021

Published: October 11, 2021 
oxidant due to its very high reduction potential and related reactivity as a one-electron oxidant of susceptible organic and inorganic electron donors $\left(E^{\circ}\left({ }^{\bullet} \mathrm{OH} / \mathrm{H}_{2} \mathrm{O}\right)=2.80 \mathrm{~V}\right.$ vs SHE $)$. Physico-chemical methods for hydroxyl radical production include ultrasonic radiation or sonolytic ozonation, ${ }^{10} \mathrm{UV} /$ $\mathrm{H}_{2} \mathrm{O}_{2}$ and $\mathrm{UV} / \mathrm{O}_{3}$ photolysis, or utilizing the $\mathrm{O}_{3} / \mathrm{H}_{2} \mathrm{O}_{2}$ peroxone reaction. ${ }^{11}$ However, these methods are limited by their operational costs. In the case of hydrogen peroxide, storage of high concentrations (e.g., $\geq 30 \%$ by weight of $\mathrm{H}_{2} \mathrm{O}_{2}$ ) requires special hazardous chemical precautions. Hydrogen peroxide is susceptible to autocatalytic decomposition into oxygen and water, which may lead to an explosion in an unvented storage container.

To avoid the high cost of $\mathrm{H}_{2} \mathrm{O}_{2}$, the electro-peroxone process (E-peroxone) can be used to produce $\mathrm{H}_{2} \mathrm{O}_{2}$ onsite via the electrochemical reduction of oxygen. Since both ozone and $\mathrm{H}_{2} \mathrm{O}_{2}$ are generated onsite with oxygen, problems associated with reagent storage are avoided.

Combining electrochemical $\mathrm{H}_{2} \mathrm{O}_{2}$ production using carbon cathodes coupled with $\mathrm{O}_{3}$ also generated onsite in a single reactor has been investigated by Wang, ${ }^{12}$ but the short lifetimes of carbon cathodes in the presence of ${ }^{\bullet} \mathrm{OH}$ make the single reactor approach challenging for practical applications. This is particularly true for small-scale treatment of wastewater in onsite, semiautonomous units where component replacement should be minimized. ${ }^{13}$ In comparison to the single-step E-peroxone process, $\mathrm{H}_{2} \mathrm{O}_{2}$ production is separated from the actual peroxone reaction chamber in order to increase the lifetime of the carbon cathodes from attack by ${ }^{\bullet} \mathrm{OH}$. The quality of the effluent from the dual-chamber reaction system is designed to be suitable for either discharge, recycling as toilet flushing water, or returned into the $\mathrm{H}_{2} \mathrm{O}_{2}$ production chamber as a source water. The system as tested is shown to be suitable for either a single-pass treatment sequence or for the continuous reuse of treated graywater as an influent for the $\mathrm{H}_{2} \mathrm{O}_{2}$ generation step. The goals of the reaction system are to meet the requirements of the standards established by NSF $350 / 350-$ for effluent quality terms of COD, TOC, BOD, $\mathrm{pH}$, and turbidity for either safe discharge into receiving waters or reuse for nonpotable water applications such as toilet and urinal flushing.

\section{SYSTEM DESIGN}

2.1. Overall Design. The electro-peroxone system developed in this study consists of two separate chambers as shown in Figure 1. The first chamber is an electrochemical $\mathrm{H}_{2} \mathrm{O}_{2}$ generator, and the second chamber is the reactor for the peroxone reaction leading to ${ }^{\circ} \mathrm{OH}$ production. A laboratoryscale prototype is shown in Figure S1 (Supporting Information). The two chambers are connected using flexible silicone tubing ( $5 \mathrm{~mm}$ ID $\times 7 \mathrm{~mm}$ OD, Uxcell, Hong Kong, China) to transfer the electrochemically generated $\mathrm{H}_{2} \mathrm{O}_{2}$ from the first reactor to the peroxone reactor using a peristaltic pump (INTLLAB, Shenzhen Jiashi Technology Co. Ltd., Shenzhen, China). Influent water (e.g., synthetic graywater) is pumped into the peroxone reactor, where it was combined with $\mathrm{O}_{3}$ and electrochemically generated $\mathrm{H}_{2} \mathrm{O}_{2}$. Finally, the treated water is either collected or recycled for use in the following cycle of treatment. Both chambers have collection ports for sampling.

2.2. Electrochemical $\mathrm{H}_{2} \mathrm{O}_{2}$ Generation. The $\mathrm{H}_{2} \mathrm{O}_{2}$ generator is a custom-designed $500 \mathrm{~mL}$ reactor made from ABS-based plastic (VisiJet Armor (M2G-CL; MJP)) that is

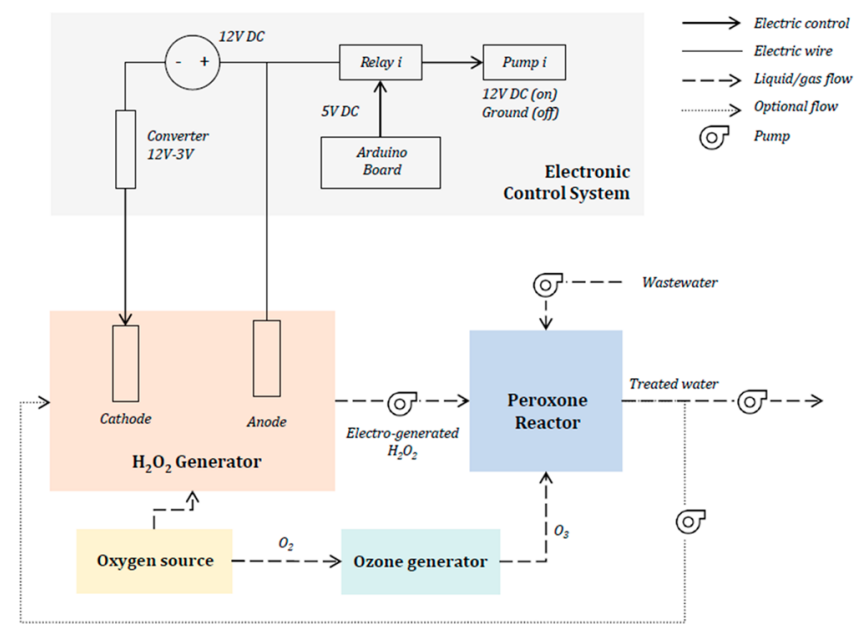

Figure 1. Schematic diagram of an integrated electro-peroxone reactor system. A single power supply provides the applied potential power for the electrolysis and to run the mechanical components needed for a continuous-flow reaction system.

3D-printed using a ProJet MJP 2500 Plus (3D SYSTEMS, Rock Hill, SC). A titanium $\mathrm{O}_{2}$ diffuser is placed along the center line and at the bottom of the reactor at a flow rate of 0.8 standard cubic feet per hour (SCFH). The electrode pair is placed above the $\mathrm{O}_{2}$ diffuser in a 3D-printed $110 \mathrm{~mm} \times 70 \mathrm{~mm}$ $\times 105 \mathrm{~mm}$ ABS-based housing, which covers the edges of the electrodes in prevent electrical shortages and to increase the mechanical stability of the electrolysis unit (Figure S2, Supporting Information). The electrolysis cell consists of three polytetrafluoroethylene (PTFE) coated carbon cathodes (CP75T carbon fiber paper, AVCARB MATERIAL SOLUTIONS, Lowell, MA) placed in a sandwich configuration between two $\mathrm{IrTaO}_{-} \mathrm{TiO}_{x}$ anodes (Nanopac, Korea). A constant electrical potential of $+3 \mathrm{~V}$ is applied between the cathodes and the anodes during $\mathrm{H}_{2} \mathrm{O}_{2}$ electrolysis. $50 \mathrm{mM}$ $\mathrm{Na}_{2} \mathrm{SO}_{4}$ (Macron Fine Chemicals, Center Valley, PA) in deionized water (Milli- $\mathrm{Q}$ Millipore) is initially used as the electrolyte. $\mathrm{H}_{2} \mathrm{O}_{2}$ is generated at the cathodes, whereas mainly oxygen gas is produced at the anodes as a half reaction of water splitting. In the subsequent treatment cycles, treated graywater is used as the electrolyte.

2.3. Peroxone Reactor. The peroxone reactor is a customized 1-L cylinder with two liquid ports and one gas infuser. The influent (i.e., synthetic graywater) is added directly from an external waste container, while $\mathrm{H}_{2} \mathrm{O}_{2}$ is transferred from the $\mathrm{H}_{2} \mathrm{O}_{2}$ generator and introduced at the bottom of the peroxone reactor using flexible tubing. An external $\mathrm{O}_{3}$ generator (CNC6390-1V, Eleoption) with an average power consumption of $65 \mathrm{~W}$ is used to convert oxygen to $\mathrm{O}_{3}$ with a $5 \%$ efficiency, delivering $71.5 \mathrm{mg} / \mathrm{L}$ of $\mathrm{O}_{3}$ to the peroxone reactor during the cycle treatment. The $\mathrm{O}_{2} / \mathrm{O}_{3}$ diffuser at $0.8 \mathrm{SCFH}$ was placed slightly above the bottom of the reactor. Mixing in the reactor is achieved by the turbulence generated by the flow of $\mathrm{O}_{2} / \mathrm{O}_{3}$. Treated wastewater is pumped out from the bottom of the cylinder to an external storage container.

2.4. Electronics and Pumps. The entire system is powered by a $12 \mathrm{~V} \mathrm{DC}, 0-30 \mathrm{~A}$ power supply (Supermight). The output voltage is converted to $3 \mathrm{~V}$ using an adjustable DC-DC converter (DROK LM2596) to drive the $\mathrm{H}_{2} \mathrm{O}_{2}$ 
generator. The output voltage is continuously monitored and displayed using a MCIGICM 0.28" LED Voltmeter Ammeter.

Liquid flow in the system is controlled by five identical INTLLAB peristaltic pumps of $3 \mathrm{~mm}$ ID $\times 5 \mathrm{~mm}$ OD, powered by the $12 \mathrm{~V} \mathrm{DC}, 0-30 \mathrm{~A}$ power supply. The flow from each pump is controlled at $100 \mathrm{~mL} / \mathrm{min}$ by five YOUNGNEER $5 \mathrm{~V}$ Relays controlled by an ARDUINO UNO R3 board.

\section{METHODS}

3.1. Treatment Sequence. The system described in section 2 was used in all of the treatment tests presented in this study. A full test sequence started with $\mathrm{H}_{2} \mathrm{O}_{2}$ generation using $0.8 \mathrm{SCFH}$ of $\mathrm{O}_{2}$ and $3 \mathrm{~V}$ of applied potential at the electrodes of the $\mathrm{H}_{2} \mathrm{O}_{2}$ generator. The $\mathrm{H}_{2} \mathrm{O}_{2}$ generation step lasted until the desired concentration of $\mathrm{H}_{2} \mathrm{O}_{2}(\sim 2.25 \mathrm{abs}$ or $4.8 \mathrm{mM})$ was reached (between 60 to $90 \mathrm{~min}$ ). A $250 \mathrm{~mL}$ solution of the electrochemically generated $\mathrm{H}_{2} \mathrm{O}_{2}$ was introduced into the peroxone reactor in three injections of equal volume, each at 0 , 10 , and $20 \mathrm{~min}$, unless noted otherwise. $\mathrm{O}_{2}$ was converted to $\mathrm{O}_{3}$ by the $\mathrm{O}_{3}$ generator and continuously introduced into the peroxone reactor at $0.8 \mathrm{SCFH}$ until the end of treatment. Aliquots of graywater were collected for chemical and physical analysis every $10 \mathrm{~min}$ for the first $60 \mathrm{~min}$ of treatment and at the end of the treatment for the last $90 \mathrm{~min}$.

3.2. Consecutive Runs. The first treatment sequence was conducted using $50 \mathrm{mM} \mathrm{Na} 2 \mathrm{SO}_{4}$ electrolyte in $500 \mathrm{~mL}$ of DI water for $\mathrm{H}_{2} \mathrm{O}_{2}$ generation. Treated graywater was used as the subsequent electrolyte for the following treatment cycles. In this case, $440 \mathrm{~mL}$ of the treated graywater was added back into the $\mathrm{H}_{2} \mathrm{O}_{2}$ reactor before electrolytic $\mathrm{H}_{2} \mathrm{O}_{2}$ generation. The submerged electrode surface area was kept constant in the $\mathrm{H}_{2} \mathrm{O}_{2}$ chamber. Two $20 \mathrm{~mL}$ glass vials were immersed in the chamber to compensate for the volume loss caused by sampling during treatment. The duration of the electrolysis of $\mathrm{H}_{2} \mathrm{O}_{2}$ was adapted to reach a concentration of $\sim 4.8 \mathrm{mM}$ $\mathrm{H}_{2} \mathrm{O}_{2}$. Following the generation of $\mathrm{H}_{2} \mathrm{O}_{2}$, all consecutive steps were identical to the full system treatment sequence as described in section 3.1. This process was repeated until the fourth treatment sequence was achieved. The reactor and associated tubing were flushed with $500 \mathrm{~mL}$ of DI water between each run.

3.3. Cyclic Voltammetry. Cyclic voltammetry (CV) was performed in a $50 \mathrm{mM} \mathrm{Na} 2 \mathrm{SO}_{4}$ solution in a four-necked flask, employing a three-electrode configuration that was connected to a Bio-Logic VSP-300 Potentiostat (Seyssinet-Pariset, France). The $\mathrm{pH}$ of the electrolyte was 5.61. The working electrode was a $1 \mathrm{~cm} \times 1 \mathrm{~cm}$ PTFE-coated carbon paper electrode exposed on a single side and covered on the backside with epoxy. A CHI $151 \mathrm{Hg} / \mathrm{HgSO}_{4}$ electrode ( $\mathrm{CH}$ Instruments, Austin TX, USA) was used as the reference electrode, while a platinum counter electrode and an outlet for gases occupied the third neck of the flask. The fourth neck was used as an inlet for nitrogen $\left(\mathrm{N}_{2}\right)$ or oxygen $\left(\mathrm{O}_{2}\right)$ gas purging. $\mathrm{N}_{2}$ or $\mathrm{O}_{2}$ was purged into the flask for saturation for $30 \mathrm{~min}$ before $\mathrm{CV}$ and then constantly purged throughout the $\mathrm{CV}$ scans. Either gas was bubbled through another $50 \mathrm{mM} \mathrm{Na} \mathrm{SO}_{4}$ solution before introduction to the flask to reduce evaporation. $\mathrm{CV}$ was performed at scan rate of $10 \mathrm{mV} / \mathrm{s}$ in the potential range of -1.0 to $0.0 \mathrm{~V}$.

3.4. Cathode Materials. The $\mathrm{H}_{2} \mathrm{O}_{2}$ production rates over 60 min using different carbon-based materials were determined (Table S1, Supporting Information). Chemical compatibility and the cost of materials were also considered. Each cathode material had the same surface area $\left(8 \mathrm{~cm}^{2}\right)$ in contact with 400 $\mathrm{mL}$ of a solution of $\mathrm{Na}_{2} \mathrm{SO}_{4}$ at $50 \mathrm{mM}$. The anode was a composite $\mathrm{IrTaO}^{\mathrm{TiO}}$ electrode (Nanopac, Korea). Oxygen was supplied at a constant flow rate of $1.7 \mathrm{SCFH}$.

3.5. Sample Collection and Characterization. First, 10 $\mathrm{mL}$ samples were collected $10 \mathrm{~cm}$ from the bottom of the peroxone reactor using a $25 \mathrm{~mL}$ pipet and were briefly stored at room temperature $\left(21 \pm 1{ }^{\circ} \mathrm{C}\right)$ before being analyzed for turbidity, $\left[\mathrm{H}_{2} \mathrm{O}_{2}\right], \mathrm{COD}, \mathrm{pH}$, and TOC. Unless noted otherwise, the measurements were performed in triplicate.

3.5.1. Turbidity. Turbidity was measured using the HI93414 Turbidity meter (Hanna Instruments, Woonsocket, USA) following the method recommended by the manufacturer.

3.5.2. $\left[\mathrm{H}_{2} \mathrm{O}_{2}\right]$. A $0.5 \mathrm{~mL}$ sample was combined with an equal volume of a titanium oxalate solution as per Sellers. ${ }^{14}$ The 407 $\mathrm{nm}$ absorbance of the resulting mix was measured by UV-vis spectroscopy using a Nanodrop 2000c spectrophotometer (Thermo Scientific, Waltham, USA). The system was blanked with Milli-Q water beforehand.

3.5.3. Chemical Oxygen Demand (COD). After appropriate dilution, COD was measured by colorimetry following Hach Method 8000 with low-range 3-150 $\mathrm{mg} \mathrm{O}_{2} / \mathrm{L}$ COD vials and a DR 900 Colorimeter (Hach, Loveland, USA). Interferences on COD measurement due to residual $\mathrm{H}_{2} \mathrm{O}_{2}$ in the peroxone reactor were monitored and stayed under $10 \mathrm{mg} \mathrm{O} / 2$.

3.5.4. $\mathrm{pH}$ Measurement. $\mathrm{pH}$ was determined using an Orion Star A215 pH/conductivity meter (Thermo Scientific, Waltham, USA) connected to an Orion 8157BNUMD Ross Ultra $\mathrm{pH} / \mathrm{ATC}$ Triode (Thermo Scientific, Waltham, USA).

3.5.5. Total Organic Carbon (TOC) and Total Inorganic Carbon (TIC). In addition to COD measurements, the Total Organic Carbon (TOC) and Total Inorganic Carbon (TIC) concentrations in the synthetic graywater samples were measured over the course of treatment using a TOC analyzer (OI Analytical Model 1030W, College Station, TX). The TOC content was obtained indirectly by subtracting the measured TIC content from the measured total carbon (TC) content. While TIC was quantified in the gas produced by phosphoric acid (5\% v/v, Fisher Scientific, Hampton, NH) treatment, TC was quantified by oxidation of all the existing carbon in the sample with $\mathrm{Na}_{2} \mathrm{~S}_{2} \mathrm{O}_{8}(10 \% \mathrm{w} / \mathrm{v}$, Acros Organics, Fair Lawn, $\mathrm{NJ}){ }^{15}$ The sample was diluted at a 1:4 ratio with Milli-Q water prior to analysis, except for the last extract obtained at $90 \mathrm{~min}$ due to its very low TOC content.

3.5.6. Total Nitrogen (TN) and Total Phosphorus (TP). Total nitrogen (TN) and total phosphorus (TP) of the synthetic graywater were determined by colorimetry using a Hach DR 900 colorimeter (Hach, Loveland, USA) at the beginning and at the end of the treatment. For the TN measurement, Hach Method 10071 was used with Test 'N Tube Low Range Total Nitrogen Reagent Set. For the TP measurement, Hach method 8190 was used with the Test ' $N$ Tube Low Range Total Phosphate Reagent Set.

3.5.7. Biochemical Oxygen Demand (BOD). Biochemical Oxygen Demand (BOD) was measured after a 5-day incubation period following Standard Method $5210 \mathrm{~B}^{16}$ using an Accumet XL40 Dissolved Oxygen Meter (Fisher Scientific, Waltham, MA) connected to an Orion BOD probe (Thermo Scientific, Waltham, MA). The samples collected after treatment $(90 \mathrm{~min})$ were bubbled with air for approximately 5 min after dilution and prior to measuring the dissolved oxygen. 
3.6. Graywater Synthesis. The synthetic graywater used in this study (Table S2, Supporting Information) was adapted from the NSF 350/350-1 standard. ${ }^{17}$ A 10-L batch of synthetic graywater was prepared in a $30-\mathrm{L}$ container by dissolving the components in tap water, except for deodorant and toothpaste. A premix solution of deodorant and toothpaste was prepared separately in $450 \mathrm{~mL}$ of tap water at $65^{\circ} \mathrm{C}$ and mixed at 700 rpm for $20 \mathrm{~min}$ and then added to the container. Finally, the synthetic graywater solution was mixed with a DLH overhead stirrer (Velp Scientifica, Usmate, Italy) at $2000 \mathrm{rpm}$ for $20 \mathrm{~min}$ and settled for $10 \mathrm{~min}$ before use. Synthetic graywater from the same batch was used for each consecutive testing. The graywater was characterized and found to be consistently within the range of water matrices described in the NSF 350/ 350-1 standard (see Table S3, Supporting Information).

\section{RESULTS AND DISCUSSION}

4.1. Single Run Testing. Removal of COD and TOC. A decrease in COD and TOC concentrations in the bulk solution of the peroxone reactor was observed during each run (Figure 2) following the treatment sequence described in section 3.1.

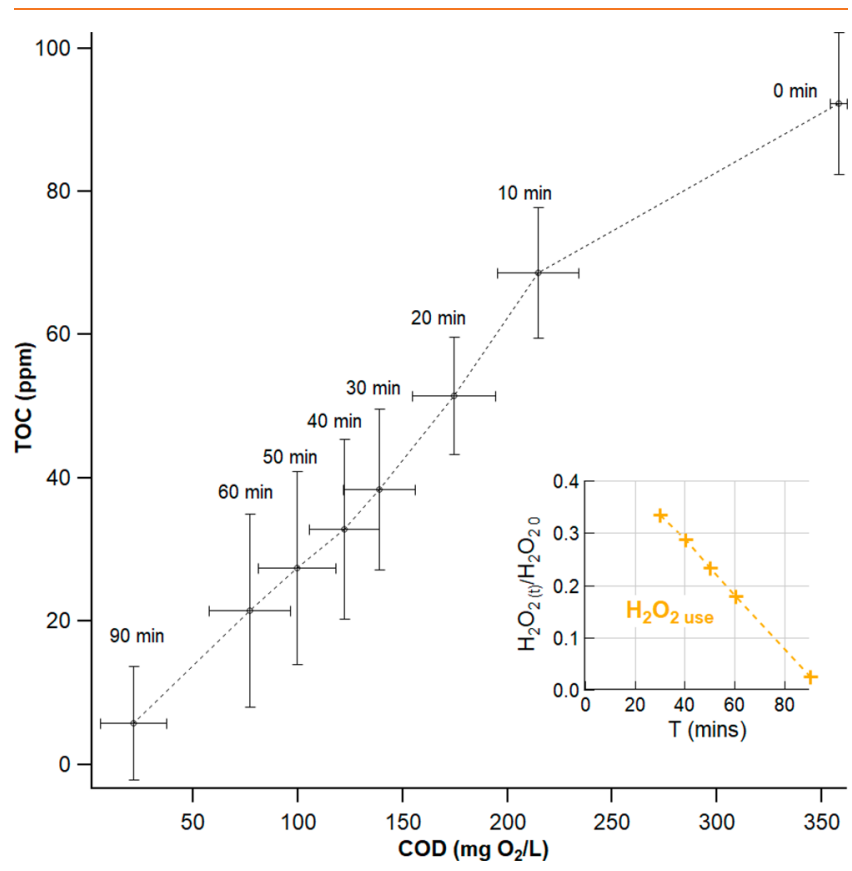

Figure 2. Co-evolution of TOC and COD concentrations in the peroxone reactor. Electrochemically generated $\mathrm{H}_{2} \mathrm{O}_{2}$ was added to the reactor in equal volumes after 0,10 , and $20 \mathrm{~min}$ of E-peroxone treatment. (Inset: concomitant evolution of $\left[\mathrm{H}_{2} \mathrm{O}_{2}\right]$ in the peroxone reactor during treatment.) Error bars represent \pm standard deviation from the mean.

Graywater had an average initial COD level of $358.5 \pm 3.8 \mathrm{mg}$ $\mathrm{O}_{2} / \mathrm{L}$ and reached a COD level of $21.25 \pm 15.70 \mathrm{mg} \mathrm{O} / 2 / \mathrm{L}$ at the end of the $90 \mathrm{~min}$ treatment run. The average percent COD removal was $94 \%$ in solution and $89 \%$ when adjusted for dilution. In addition to observing COD removal, the TOC of the solution was degraded by $92 \%$ ( $86 \%$ adjusted for dilution) during the E-peroxone process with starting TOC concentrations of $96.95 \pm 9.84 \mathrm{mg} / \mathrm{L}$ and final TOC concentrations of $7.29 \pm 7.86 \mathrm{mg} / \mathrm{L}$. As a comparison, conventional ozonation was performed by substituting $\mathrm{H}_{2} \mathrm{O}_{2}$ with Milli-Q water added to the system in the same injection patterns $(0 \mathrm{~min}, 10 \mathrm{~min}$, and $20 \mathrm{~min}$ ), and we observed both COD and TOC removals of only $57 \%$ and $43 \%$, respectively. The large difference between injection of $\mathrm{H}_{2} \mathrm{O}_{2}$ solution or Milli-Q water confirms that the E-peroxone treatment was more effective at oxidizing and mineralizing organics than ozonation alone. ${ }^{11}$

The decrease of COD and TOC concentration over time was not linear (Figure 2). COD and TOC decreased by an average of $34 \%$ and $27 \%$ during the first $10 \mathrm{~min}$ of the process, while this removal was of approximately $19 \%$ and $20 \%$ during the next $10 \mathrm{~min}$ increments, with limited effect of the injection of the electrochemically generated $\mathrm{H}_{2} \mathrm{O}_{2}$ solution. This difference between the initial rate and the rest can be attributed to the fact that there is a high concentration of organic species at the beginning of the treatment, leading to a higher removal efficacy. In addition, the fluctuation of the COD/TOC ratio (i.e., deviation from a constant) during the process was likely caused by organic matter not readily biodegradable or other recalcitrant organic contaminants in the solution. $^{18}$

Finally, the removal efficacy observed for COD and TOC was upheld with regard to BOD elimination: the BOD decreased by $95 \%$ ( $91 \%$ adjusted for dilution) to reach, on average, $7.83 \pm 6.49 \mathrm{mg} \mathrm{O} / \mathrm{L}\left(14.32 \mathrm{mg} \mathrm{O}_{2} / \mathrm{L}\right.$ adjusted for dilution). The effluent met the NSF350/350-1 Class $\mathrm{R}$ requirement for BOD $(\mathrm{BOD}<10 \mathrm{mg} / \mathrm{L})$.

Turbidity, $p H, T N$, and TP. The turbidity of synthetic graywater was initially $11.2 \mathrm{NTU}$. After $90 \mathrm{~min}$ of treatment (Figure S3, Supporting Information), the turbidity decreased by $95 \%$. Given that the graywater was mixed with the $\mathrm{H}_{2} \mathrm{O}_{2}$ containing $\mathrm{Na}_{2} \mathrm{SO}_{4}$ solution in equal volumes during treatment, the observed turbidity reduction of graywater was partly caused by dilution. To evaluate the influence of dilution on the turbidity reduction, synthetic graywater was diluted with Milli$\mathrm{Q}$ water at a 1:1 ratio with and without continuous oxygen flow through the peroxone reactor. In the 1:1 mixture of graywater and Milli-Q water, the turbidity decreased only by $42 \%$ with constant oxygen flow and by $47 \%$ without it. The small difference in turbidity reduction with and without oxygen can be attributed to the oxygen flow favoring the suspension of particles that were prone to adhering to the reactor wall. Conversely, the vast improvement in turbidity removal during the E-peroxone process correlated with the high TOC and COD removal (vide supra) of this process. Small particles in suspension can be chemically oxidized and dissolve, as observed in agro-industrial wastewaters. ${ }^{19}$ The results indicate that the E-peroxone process reduced the turbidity of graywater effectively enough to meet the NSF 350/350-1 standard for both Class $\mathrm{R}(<5 \mathrm{NTU})$ and Class $\mathrm{C}(<2 \mathrm{NTU})$.

The $\mathrm{pH}$ remained stable (between 6.5 and 8 ) and met the NSF 350/350-1 standard $(6<\mathrm{pH}<9)$ range (Figure S4, Supporting Information). On average, the $\mathrm{pH}$ decreased slowly from 7.8 to 7.0 during the first hour of treatment, most likely due to intermediate organic acid production in the system from peroxone-driven oxidation reactions. ${ }^{5}$ The addition of the $\mathrm{H}_{2} \mathrm{O}_{2}$ solution, whose $\mathrm{pH}$ was 7.53 , did not influence the $\mathrm{pH}$ in the peroxone reactor as synthetic graywater was composed of a variety of buffering agents such as bicarbonates. However, the constant $\mathrm{O}_{2} / \mathrm{O}_{3}$ flow resulted in the stripping of newly generated $\mathrm{CO}_{2}$ generated during mineralization of the organic constituents. Therefore, the $\mathrm{pH}$ rose to 7.3. A similar effect was observed by Cohen and co-workers. ${ }^{20}$ The change in $\mathrm{pH}$ was reflected in an increase of TIC (i.e., carbonate alkalinity) during the last $30 \mathrm{~min}$ of treatment, as shown in Figure S5 of the Supporting Information. 
The electrochemical peroxone process did not readily remove $\mathrm{TN}$ and $\mathrm{TP}$ in synthetic graywater at initial concentrations of $5.10 \mathrm{mg} / \mathrm{L}$ and $3.93 \mathrm{mg} / \mathrm{L}$, respectively. Considering the dilution of the graywater with $\mathrm{H}_{2} \mathrm{O}_{2}$ containing $\mathrm{Na}_{2} \mathrm{SO}_{4}$ solution, TN nearly remained the same, whereas TP decreased by $33 \%$ after $90 \mathrm{~min}$ of treatment. Moghadam et al. observed that the efficacy of phosphorus removal can be improved by favoring the peroxone reaction by increasing $\mathrm{pH}^{21}$ As a result, synthetic graywater can be adjusted with higher $\mathrm{pH}$ before treatment, as the kinetics of $\mathrm{OH}$ formation are enhanced under basic conditions, ${ }^{12}$ for more effective phosphorus removal. TP removal could also be attributed to the removal of some suspended solids floating on top of the peroxone chamber (Kasak et al. obtained up to $44 \%$ phosphorus removal by filtering graywater). ${ }^{22}$ On the other hand, AOPs such as the E-peroxone process that is based on - $\mathrm{OH}$ as the primary oxidant are known to be ineffective for nitrogen removal. For example, ammonium ion/ammonia reacts with ${ }^{\circ} \mathrm{OH}$ at much slower rates than oxidizable contaminants. ${ }^{23}$ Therefore, integrating the E-peroxone process with an additional treatment step (e.g., ion exchange, activated carbon $^{24}$ or chlorination ${ }^{25}$ ) may lead to improvement of the nitrogen removal efficiency in the case of graywater. This integration would expand the scope of application of the Eperoxone process for treating human wastewater that has higher nitrogen loads.

4.2. Consecutive Testing. The COD removal $\left(\mathrm{COD}_{\mathrm{rem}}\right)$ extent remained above $300 \mathrm{mg} \mathrm{O} / \mathrm{L}$ for each $90 \mathrm{~min}$ treatment run (Figure 3) with a small decline from $337.25 \pm$

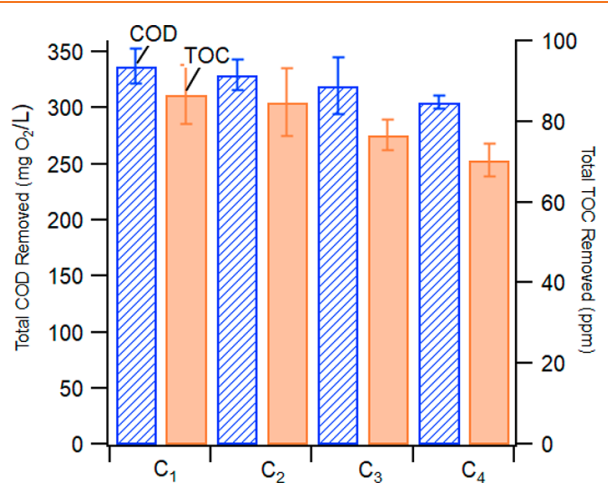

Figure 3. Average $\mathrm{COD}$ removal $\left(\mathrm{COD}_{\text {rem }}\right)$ and TOC removal $\left(\mathrm{TOC}_{\mathrm{rem}}\right)$ from graywater during four consecutive treatment cycles $\left(\mathrm{C}_{1}\right.$ through $\left.\mathrm{C}_{4}\right)$. Error bars represent \pm standard deviation from the mean.

$15.17 \mathrm{mg} \mathrm{O}_{2} / \mathrm{L}\left(\mathrm{C}_{1}\right)$ to $305 \pm 5.7 \mathrm{mg} \mathrm{O}_{2} / \mathrm{L}\left(\mathrm{C}_{4}\right)$. Similarly, TOC removal $\left(\right.$ TOC $_{\text {rem }}$ ) remained above $70 \mathrm{mg} / \mathrm{L}$ for each 90 min treatment run (Figure 3) but with a slightly more significant decline: from $86.63 \pm 7.35 \mathrm{mg} / \mathrm{L}\left(\mathrm{C}_{1}\right)$ to $70.35 \pm$ $4.2 \mathrm{mg} / \mathrm{L}\left(\mathrm{C}_{4}\right)$. Despite the decrease in TOC removal efficiency, the graywater quality standards were maintained for COD and TOC, even when the effluent was recycled into the $\mathrm{H}_{2} \mathrm{O}_{2}$ generator four times. The treatment performance declined faster after a fifth treatment cycle, potentially due to the decrease in electrolytic $\mathrm{H}_{2} \mathrm{O}_{2}$ production due to a stepwise reduction in conductivity (vide infra). The decline in $\mathrm{COD}_{\text {rem }}$ and $\mathrm{TOC}_{\text {rem }}$ over consecutive cycles can be explained by two main factors: (1) the impact of the recycled effluent and (2) the decrease in $\mathrm{H}_{2} \mathrm{O}_{2}$ production (Table S4, Supporting Information).
The COD $\mathrm{Crm}_{\text {and }} \mathrm{TOC}_{\text {rem }}$ decreases may also be due to the accumulation of organics in the system as the effluent from $\mathrm{C}_{1}$ $\left(\mathrm{Ef}_{1}\right)$ was recycled for $\mathrm{H}_{2} \mathrm{O}_{2}$ electro-generation in $\mathrm{C}_{2}$, the value of COD Ef $\mathrm{E}_{1}=21.25 \pm 15.71 \mathrm{mg} \mathrm{O} \mathrm{O}_{2} / \mathrm{L}$ and $\mathrm{TOC} \mathrm{Ef}_{1}=7.29 \pm$ $7.86 \mathrm{mg} / \mathrm{L}$ (the $\mathrm{Na}_{2} \mathrm{SO}_{4}$ electrolyte solution used in $\mathrm{C}_{0}$ had no detectable amounts of COD or TOC). COD and TOC in $\mathrm{Ef}_{1}$ did not degrade during the electro-generation of $\mathrm{H}_{2} \mathrm{O}_{2}$ (data not shown). As a result, COD and TOC values increased in $\mathrm{C}_{2}$ compared to $\mathrm{C}_{1}$ when the electro-generated $\mathrm{H}_{2} \mathrm{O}_{2}$ solution from $\mathrm{Ef}_{1}$ was injected into the peroxone reactor. The same phenomenon was accentuated in the subsequent cycles $\left(\mathrm{C}_{3}\right.$ and $\mathrm{C}_{4}$ ).

The second factor impacting $\mathrm{COD}_{\text {rem }}$ and $\mathrm{TOC}_{\text {rem }}$ decrease is the lower $\left[\mathrm{H}_{2} \mathrm{O}_{2}\right]$ in the electro-generated solution that was injected into the peroxone reactor. This decrease is attributed to a loss of conductivity (vide infra). Because the peroxone reactor is saturated with $\mathrm{O}_{3}, \mathrm{H}_{2} \mathrm{O}_{2}$ is the limiting reagent in the peroxone process. Consequently, the decrease of $\left[\mathrm{H}_{2} \mathrm{O}_{2}\right]$ in the solution injected into the peroxone reactor leads to a decrease of the steady state $\left[{ }^{\bullet} \mathrm{OH}\right]$, which in turn impacts the degradation of organic components.

4.3. Effects of Recycling Treated Graywater on Electrochemical $\mathrm{H}_{2} \mathrm{O}_{2}$ Generation. The amount of time required to obtain an adequate $\left[\mathrm{H}_{2} \mathrm{O}_{2}\right]$ (i.e., $4.8 \mathrm{mM}$ ) increased for each consecutive treatment test as treated graywater was recycled from the previous cycle for use in the electrochemical $\mathrm{H}_{2} \mathrm{O}_{2}$ production reactor. The increase of $\mathrm{H}_{2} \mathrm{O}_{2}$ generation time over multiple cycles is attributed to the change in the chemical composition of the electrolyte solution (i.e., as treated graywater is recycled). First, the solution conductivity is drastically reduced as the original $50 \mathrm{mM}$ $\mathrm{Na}_{2} \mathrm{SO}_{4}$ electrolyte solution at a conductivity of $8 \mathrm{mS} / \mathrm{cm}$ is mixed and diluted with graywater with a much lower conductivity of $\sim 0.7 \mathrm{mS} / \mathrm{cm}$ to produce $\mathrm{H}_{2} \mathrm{O}_{2}$ in subsequent cycles. In addition, a fraction of $\mathrm{H}_{2} \mathrm{O}_{2}$ may be simultaneously consumed by the organic compounds remaining in treated graywater due to incomplete organic mineralization. However, if treated graywater contains a high concentrations of chloride, reactive chlorine species (RCS) including hypochlorous acid $(\mathrm{HOCl})$ and hypochlorite ions will be produced at the anode ${ }^{26}$ during the reductive electrochemical generation of $\mathrm{H}_{2} \mathrm{O}_{2}$ generation, resulting in a counterproductive scavenging of the generated $\mathrm{H}_{2} \mathrm{O}_{2}$.

To reproduce the decreasing conductivity observed over the course of consecutive tests, the original $50 \mathrm{mM} \mathrm{Na}_{2} \mathrm{SO}_{4}$ electrolyte solution was diluted with Milli-Q water at varying percentages: $50 \%, 25 \%$, and $12.5 \%$. Therefore, the electrolyte conductivity decreased proportionally by the dilution factors as shown in Table 1. Isolating the conductivity as a primary variable eliminates the potential impacts of residual organics in

Table 1. $\mathrm{Na}_{2} \mathrm{SO}_{4}$ Electrolyte Concentration $\left[\mathrm{Na}_{2} \mathrm{SO}_{4}\right]_{0}$, Conductivity, Final $\left[\mathrm{H}_{2} \mathrm{O}_{2}\right]$ Produced, Total Charge Passed in Each Solution, and Faradaic Efficiency for $\mathrm{H}_{2} \mathrm{O}_{2}$ Generation, the Latter Calculated Based on the Final $\left[\mathrm{H}_{2} \mathrm{O}_{2}\right]$ and the Total Charge Passed

$\begin{array}{lcccc}{\left[\mathrm{Na}_{2} \mathrm{SO}_{4}\right]_{0}(\mathrm{mM})} & 50.0 & 25.0 & 12.5 & 6.25 \\ \text { conductivity }(\mathrm{mS} / \mathrm{cm}) & 7.664 & 4.135 & 2.217 & 1.171 \\ \text { final }\left[\mathrm{H}_{2} \mathrm{O}_{2}\right](\mathrm{mM}) & 5.529 & 4.091 & 3.187 & 2.278 \\ \text { total charge passed }(\mathrm{C}) & 812.14 & 612.36 & 475.34 & 314.51 \\ \text { Faradaic efficiency (\%) } & 65.69 & 64.46 & 64.69 & 64.89\end{array}$


recycled treated graywater and of RCS formation on the net production of $\mathrm{H}_{2} \mathrm{O}_{2}$. Figure 4 shows a decrease in $\mathrm{H}_{2} \mathrm{O}_{2}$

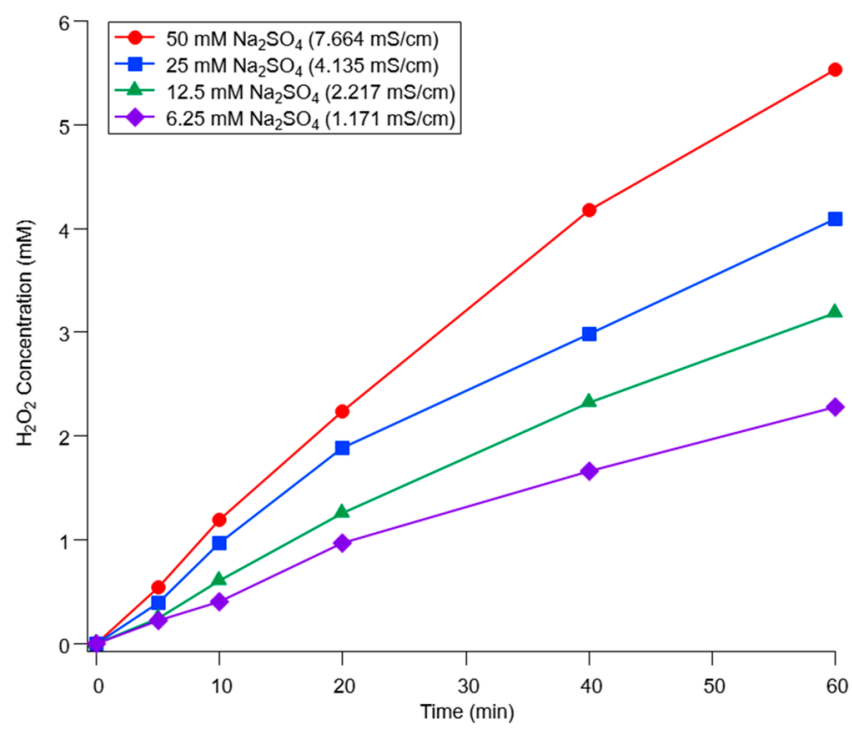

Figure 4. $\mathrm{H}_{2} \mathrm{O}_{2}$ generation in $\mathrm{Na}_{2} \mathrm{SO}_{4}$ electrolyte solutions at varying concentrations. $\mathrm{H}_{2} \mathrm{O}_{2}$ was generated for $60 \mathrm{~min}$ in the same setups as described in section 2.2, except that a potentiostat was used to apply $3.00 \mathrm{~V}$ of DC and measure the total electric charge for each electrolyte solution tested.

production due to decreasing conductivity in proportion to the actual $\mathrm{Na}_{2} \mathrm{SO}_{4}$ concentration. Lower electrolyte solution conductivity also increases the potential drop between the anode and the cathode in solution, thereby decreasing the total charge passed in the system as each test was run at a constant voltage. The Faradaic efficiency of each run was calculated based on the total moles of $\mathrm{H}_{2} \mathrm{O}_{2}$ generated and the total charge passed during the $60 \mathrm{~min}$ electrolyses. Table 1 shows that the Faradaic efficiency, which is proportional to the total moles of $\mathrm{H}_{2} \mathrm{O}_{2}$ produced and the inverse of total charge passed, remained unchanged regardless of the electrolyte conductivity. The constant Faradaic efficiency indicates that other factors such as electrocatalytic activity loss and parasitic side reactions ${ }^{28,29}$ were not present to suppress the $\mathrm{H}_{2} \mathrm{O}_{2}$ generation efficiency. Therefore, the electrolyte conductivity, which was reduced during the reuse of treated graywater as an influent to the first-stage reactor, was the primary factor increasing the extended time required to produce the same concentration of $\mathrm{H}_{2} \mathrm{O}_{2}$.

$\mathrm{H}_{2} \mathrm{O}_{2}$ has a high reduction potential of $E^{\circ}=1.76 \mathrm{~V}$, although less than for $\mathrm{O}_{3}\left(E^{\circ}=2.05 \mathrm{~V}\right)$ and or hydroxyl radical $\left(E^{\circ}=\right.$ $2.85 \mathrm{~V})$, which makes it a viable oxidizing agent for organic carbon in wastewater, especially when activated (e.g., UV radiation, the Fenton reaction, or by peroxidases). If the concentrations of oxidizable organic compounds in the treated graywater are high enough, then $\mathrm{H}_{2} \mathrm{O}_{2}$ produced in the first reactor may be consumed by the remaining organics, thereby increasing the time to achieve the target concentration of $\mathrm{H}_{2} \mathrm{O}_{2}$. As expected, when untreated graywater was mixed at a 1:1 volume ratio with a clean electrolyte solution, the concentration of $\mathrm{H}_{2} \mathrm{O}_{2}$, which was $4.8 \mathrm{mM}$ at time $=0 \mathrm{~min}$, decreased by $40 \%$ after $60 \mathrm{~min}$ of contact time (Table S5, Supporting Information). On the other hand, the loss of $\mathrm{H}_{2} \mathrm{O}_{2}$ was negligible in a mixture of treated graywater containing very low levels of oxidizable species after treatment with ${ }^{\bullet} \mathrm{OH}$ and $\mathrm{O}_{3}$ in the peroxone reactor.

If chloride is present in the influent to the first reactor, then $\mathrm{HOCl} /{ }^{-} \mathrm{OCl}$ (i.e., RCS) would be produced at the anode, while $\mathrm{H}_{2} \mathrm{O}_{2}$ is generated at the carbon cathode. The formation of $\mathrm{HOCl}$ leads to direct scavenging of $\mathrm{H}_{2} \mathrm{O}_{2}$ as follows: ${ }^{27}$

$$
\begin{array}{r}
\mathrm{HOCl}+\mathrm{H}_{2} \mathrm{O}_{2} \rightarrow \mathrm{H}^{+}+\mathrm{Cl}^{-}+\mathrm{H}_{2} \mathrm{O}+\mathrm{O}_{2}, \\
k_{2}=1.10 \times 10^{4} \mathrm{M}^{-1} \mathrm{~s}^{-1}
\end{array}
$$

For example, when $\mathrm{H}_{2} \mathrm{O}_{2}$ and $\mathrm{HOCl}$ were combined in an equimolar molar ratio with initial concentrations of $4.8 \mathrm{mM}$, the concentration of $\mathrm{H}_{2} \mathrm{O}_{2}$ decreased by $30 \%$ after $60 \mathrm{~min}$ (Table S6, Supporting Information). However, analysis by ion chromatography (data not shown) confirmed that the concentration of chloride $(<1 \mathrm{mM})$ in graywater was too low to produce a significant amount of $\mathrm{HOCl}$ during electrochemical $\mathrm{H}_{2} \mathrm{O}_{2}$ generation. The reaction of $\mathrm{H}_{2} \mathrm{O}_{2}$ and $\mathrm{HOCl}$, however, may play a more significant role during electrochemical $\mathrm{H}_{2} \mathrm{O}_{2}$ generation for recycled waters with higher concentrations of chloride (e.g., toilet wastewater or brackish water).

4.4. Dosage of $\mathrm{H}_{2} \mathrm{O}_{2}$ into the Peroxone Reactor. The dosage of $\mathrm{H}_{2} \mathrm{O}_{2}$ was determined based on the $\mathrm{H}_{2} \mathrm{O}_{2}$ depletion
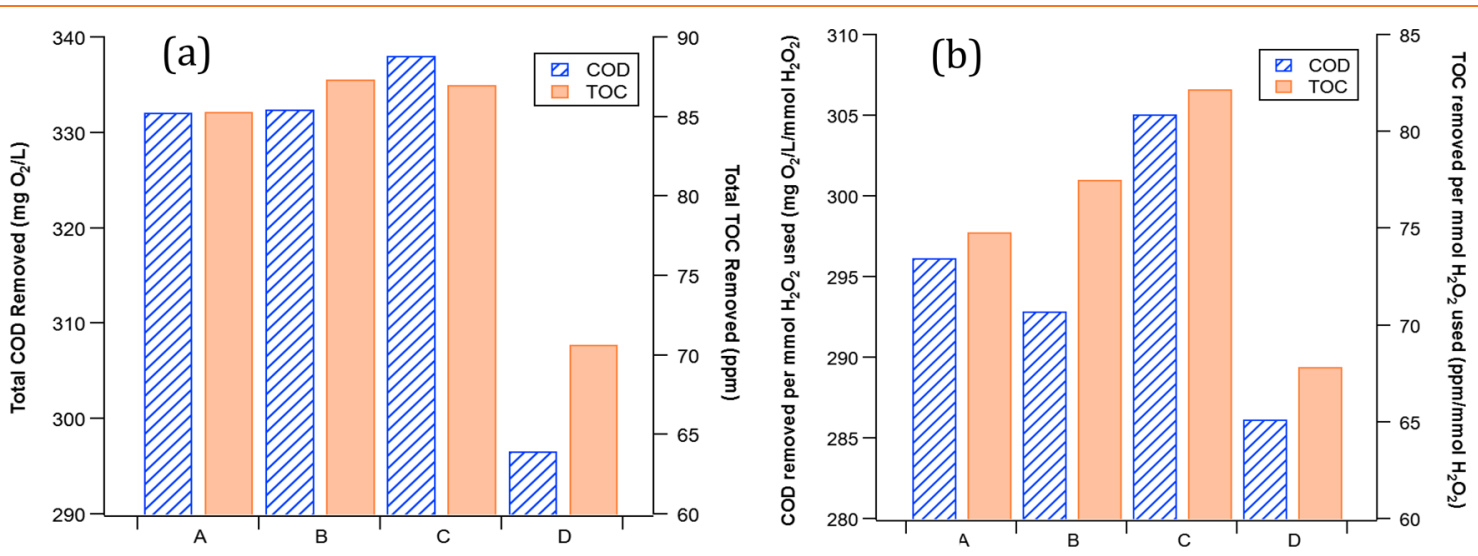

Figure 5. Total COD and TOC removal amounts (a) and COD and TOC removal amounts per $\mathrm{mmol}_{2} \mathrm{O}_{2}$ used (b). For the 90 min treatment time frame, $250 \mathrm{~mL}$ of the $\mathrm{H}_{2} \mathrm{O}_{2}$ solution was added to the peroxone reactor completely at the beginning in experiment $\mathrm{A}$, whereas three identical portions of the stage-one reactor solution were applied in the beginning and then at the $5 \mathrm{~min}$ and 10 min marks in experiment $\mathrm{B}$, at the 10 min and 20 min marks in experiment $\mathrm{C}$, and at the 20 min and 40 min marks in experiment D. 
rate observed in the peroxone reactor. Excess $\mathrm{H}_{2} \mathrm{O}_{2}$ in the second-stage reactor will react with in situ ${ }^{\bullet} \mathrm{OH} .^{30,31}$

$$
\bullet \mathrm{OH}+\mathrm{H}_{2} \mathrm{O}_{2} \rightarrow \mathrm{HO}_{2}^{\bullet}+\mathrm{H}_{2} \mathrm{O}, k_{2}=2.70 \times 10^{7} \mathrm{M}^{-1} \mathrm{~s}^{-1}
$$

Therefore, the rate of $\mathrm{H}_{2} \mathrm{O}_{2}$ transfer from the first-stage reactor to the peroxone reactor is optimized such that ${ }^{\bullet} \mathrm{OH}$ reacts with the target organic molecules in graywater without being scavenged by unreacted $\mathrm{H}_{2} \mathrm{O}_{2}$. To maximize the use of $\mathrm{H}_{2} \mathrm{O}_{2}$ for the generation of ${ }^{\bullet} \mathrm{OH}, 250 \mathrm{~mL}$ of the electrochemically generated $\mathrm{H}_{2} \mathrm{O}_{2}$ solution was injected into the peroxone reactor in three time-separated increments during the treatment. Each $83 \mathrm{~mL}$ volume of the $\mathrm{H}_{2} \mathrm{O}_{2}$ solution was injected at the beginning of the treatment and subsequently at $5 \mathrm{~min}$ (experiment B), $10 \mathrm{~min}$ (experiment C), and $20 \mathrm{~min}$ (experiment D) intervals, while the control experiment (experiment A) introduced $250 \mathrm{~mL}$ of the electrochemically generated $\mathrm{H}_{2} \mathrm{O}_{2}$ solution as one addition at the beginning of the treatment experiment. The additional experimental parameters are given in section 3.1 (see above). The treatment efficacies in terms of total COD and TOC removal and treatment efficiencies in terms of COD and TOC removal per millimole of $\mathrm{H}_{2} \mathrm{O}_{2}$ used were examined for each experiment to optimize the $\mathrm{H}_{2} \mathrm{O}_{2}$ introduction intervals for more efficient use of $\mathrm{H}_{2} \mathrm{O}_{2}$ and to obtain a higher extent of graywater mineralization (Figure 5).

The loss of treatment efficacy, observed when the entire $\mathrm{H}_{2} \mathrm{O}_{2}$ solution was introduced simultaneously at the start of treatment, is reflective of unreacted $\mathrm{H}_{2} \mathrm{O}_{2}$ scavenging by ${ }^{\circ} \mathrm{OH}$, which accelerated the depletion of $\mathrm{H}_{2} \mathrm{O}_{2}$ in a nonproductive fashion. ${ }^{30}$ On the other hand, spacing the $\mathrm{H}_{2} \mathrm{O}_{2}$ additions during the treatment allowed for the nearly complete reaction of $\mathrm{H}_{2} \mathrm{O}_{2}$ with $\mathrm{O}_{3}$ at an optimal stoichiometric molar ratio of $1: 2^{32}$ to produce ${ }^{\circ} \mathrm{OH}$ before the subsequent addition. This approach led to an enhancement in treatment performance. Not only did total COD and TOC removal improve with longer intervals between $\mathrm{H}_{2} \mathrm{O}_{2}$ injections (Figure 5a), the COD and TOC removal efficiency per millimole of $\mathrm{H}_{2} \mathrm{O}_{2}$ followed the same trend (Figure $5 \mathrm{~b}$ ). However, the longer intervals between each introduction resulted in a lower $\mathrm{H}_{2} \mathrm{O}_{2}$ concentration than stoichiometrically needed before the following injection. As a result, the peroxone generation was impeded and therefore limited the overall treatment performance. It is important to note that optimal $\mathrm{H}_{2} \mathrm{O}_{2}$ addition timings may be highly dependent on the composition of wastewater to be treated. For example, wastewater with a higher COD (i.e., containing more oxidizable species) may allow for reduced intervals between each $\mathrm{H}_{2} \mathrm{O}_{2}$ addition and allow for ${ }^{\bullet} \mathrm{OH}$ to react with the oxidizable substrates. For the synthetic graywater used herein, $10 \mathrm{~min}$ intervals were found to be the optimal condition to achieve the most efficient $\mathrm{H}_{2} \mathrm{O}_{2}$ use and highest treatment performance.

4.5. Electrochemical $\mathrm{H}_{2} \mathrm{O}_{2}$ Generation with a PTFECoated Carbon Paper Cathode. Commercially available carbon-based electrodes (Table S1) were characterized and compared in terms of electrocatalytic activity for $\mathrm{H}_{2} \mathrm{O}_{2}$ production, chemical stability, and cost of material. Table 2 lists the $60 \mathrm{~min}$ averaged $\mathrm{H}_{2} \mathrm{O}_{2}$ production rates for each electrode of interest at varying current densities: $1 \mathrm{~mA} / \mathrm{cm}^{2}, 2$ $\mathrm{mA} / \mathrm{cm}^{2}$, and $5 \mathrm{~mA} / \mathrm{cm}^{2}$. The applied potential for each test was located between 2 and 5 V. For each current density tested, CP75T carbon paper (AVCARB, Lowell, USA) provided the highest $\mathrm{H}_{2} \mathrm{O}_{2}$ production rate. Moreover, CP75T was coated with PTFE, rendering its surface
Table 2. $60 \mathrm{~min}$ Averaged $\mathrm{H}_{2} \mathrm{O}_{2}$ Production Rates for Different Cathodes As a Function of Current Density ${ }^{a}$

$\begin{array}{lccc} & \begin{array}{c}1 \mathrm{~mA} \mathrm{~cm} \\ (\mu \mathrm{M} / \mathrm{min})\end{array} & \begin{array}{c}2 \mathrm{~mA} \mathrm{~cm} \\ (\mu \mathrm{M} / \mathrm{min})\end{array} & \begin{array}{c}5 \mathrm{~mA} \mathrm{~cm} \\ (\mu \mathrm{M} / \mathrm{min})\end{array} \\ \text { CP75T } & 4.21 & 14.33 & 17.97 \\ \text { G100 } & 0.00 & 0.43 & 15.40 \\ \text { C100 } & 1.35 & 5.45 & 8.91 \\ \text { RVC 80 PPI } & 2.00 & 2.42 & 0.89 \\ \text { MGL 190 } & 0.00 & 3.85 & 0.00\end{array}$

${ }^{a}$ More details about each material can be found in Table S1 of the Supporting Information.

invulnerable to attacks by weak acids and bases present in wastewater. $^{33}$ The PTFE coating enhanced not only the chemical stability but also the mechanical properties of the carbon paper, including tensile strength at the break-in machine direction, which is $F_{\text {TUCP75T }}=20 \mathrm{MPa}$ for the carbon paper electrode with PTFE coating, compared to $F_{\mathrm{TUCP} 75}=6.5$ $\mathrm{MPa}$ for the carbon paper electrode without PTFE coating. As a result, CP75T was less susceptible to mechanical stress caused by the bubbling of the $\mathrm{O}_{2}$ flow in the $\mathrm{H}_{2} \mathrm{O}_{2}$ chamber than other electrodes without PTFE coating. Last, the price of the CP75T was in the middle range among all candidates ( $\$ 0.6875$ per $\mathrm{cm}^{2}$ on Fuelcellstore.com). In addition to the material of the electrodes, the optimization of the electrolyzer (e.g., hydraulic residence time of the electrolyte and interelectrode distance) can further improve $\mathrm{H}_{2} \mathrm{O}_{2}$ production. $^{34}$

The selected PTFE-coated carbon paper was used as a cathode to confirm the $\mathrm{H}_{2} \mathrm{O}_{2}$ generation via $\mathrm{O}_{2}$ reduction by performing $\mathrm{CV}$ under oxygenated $\left(\mathrm{O}_{2}\right.$ purging) and deoxygenated $\left(\mathrm{N}_{2}\right.$ purging $)$ conditions. Figure 6 shows cathodic currents with a reduction peak around $0.05 \mathrm{~V}$ vs RHE under $\mathrm{O}_{2}$ purging, whereas no reduction peak is visible under $\mathrm{N}_{2}$ purging. Therefore, the reduction of $\mathrm{O}_{2}$ to $\mathrm{H}_{2} \mathrm{O}_{2}$ took place at the cathode and appeared as the reduction peak under saturation with $\mathrm{O}_{2} .{ }^{35}$ The remaining cathodic currents beyond

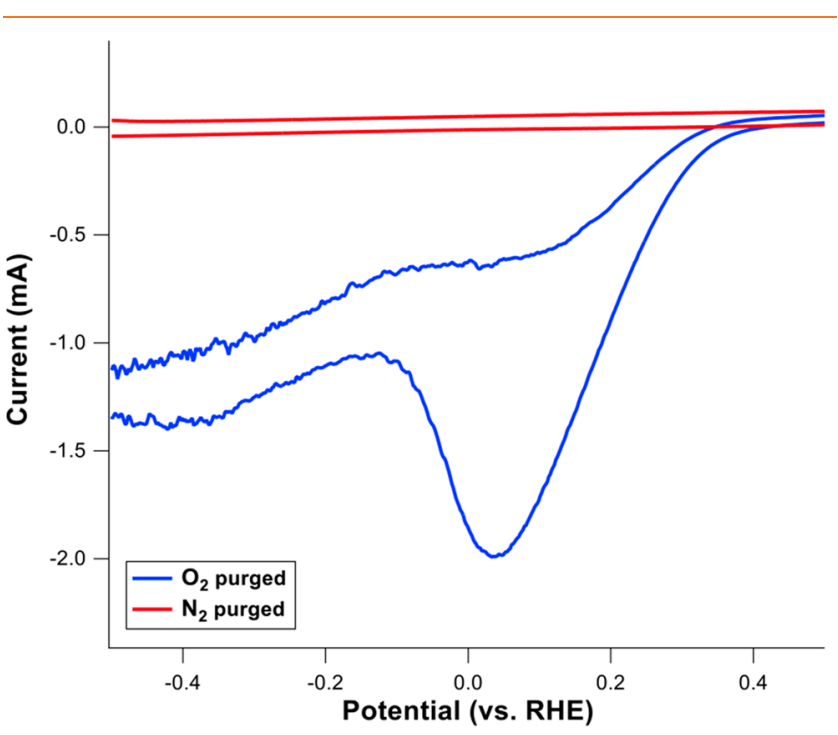

Figure 6. Cyclic voltammograms of PTFE-coated carbon paper electrode under oxygenated and deoxygenated conditions in $50 \mathrm{mM}$ $\mathrm{Na}_{2} \mathrm{SO}_{4}$. Characteristic $\mathrm{O}_{2}$ reduction peak for $\mathrm{H}_{2} \mathrm{O}_{2}$ production is only visible under saturation with $\mathrm{O}_{2}$. 
$0.05 \mathrm{~V}$ under the oxygenated and deoxygenated conditions are attributed to hydrogen evolution reaction.

\section{CONCLUSIONS}

The laboratory-scale treatment of synthetic graywater in an uncoupled E-peroxone process is explored in this study. By separating the in situ electrochemical production of $\mathrm{H}_{2} \mathrm{O}_{2}$ from the main reaction chamber in which ${ }^{\circ} \mathrm{OH}$ is generated, the process not only extends the lifetime of the carbon-PTFE electrodes that are susceptible to degradation by ${ }^{\circ} \mathrm{OH}$ but also allows for a finer control over $\mathrm{H}_{2} \mathrm{O}_{2}$ utilization to maximize the - $\mathrm{OH}$ formation. Three equal volumes of the electrochemically prepared $\mathrm{H}_{2} \mathrm{O}_{2}$ solution were added to the main chamber in 10 min intervals to achieve the highest COD and TOC removals and the most efficient use of $\mathrm{H}_{2} \mathrm{O}_{2}$. The uncoupled, sequenced E-peroxone process removed $89 \%$ of COD, $86 \%$ of TOC, and $91 \%$ of BOD and provided a $95 \%$ lowering of turbidity from synthetic graywater after $90 \mathrm{~min}$ of treatment. The resulting effluent meets most of the requirements (e.g., COD, TOC, BOD, $\mathrm{pH}$, and turbidity) established in the NSF 350/350-1 standard for the safe discharge and reuse of nonpotable water applications such as toilet and urinal flushing. Moreover, the process recycles a portion of the effluent for the subsequent electrochemical production of $\mathrm{H}_{2} \mathrm{O}_{2}$. The time necessary to reach $\left[\mathrm{H}_{2} \mathrm{O}_{2}\right] \approx 4.8 \mathrm{mM}$ slightly increased from cycle to cycle due to decreasing solution conductivity. Nevertheless, the overall reaction process maintained removal levels above $85 \%$ (COD) and $73 \%$ (TOC) over four consecutive cycles without the addition of clean water or additional electrolyte solution into the system. The two-stage E-peroxone system can be integrated with other wastewater treatment technologies (e.g., activated carbon or chlorination) to overcome limitations of the E-peroxone process (e.g., nitrogen removal) and to allow for effective onsite treatment of human wastewater in remote areas.

\section{ASSOCIATED CONTENT}

\section{SI Supporting Information}

The Supporting Information is available free of charge at https://pubs.acs.org/doi/10.1021/acsestengg.1c00240.

Figures S1-S5 and Tables S1-S6 (PDF)

\section{AUTHOR INFORMATION}

\section{Corresponding Author}

Clément A. Cid - Department of Environmental Science and Engineering, California Institute of Technology, Pasadena, California 91125, United States; (1) orcid.org/0000-00027293-035X; Email: ccid@caltech.edu

\section{Authors}

Léopold Dobelle - Department of Environmental Science and Engineering, California Institute of Technology, Pasadena, California 91125, United States

Seungkyeum Kim - Department of Chemical Engineering, California Institute of Technology, Pasadena, California 91125, United States

Axl X. LeVan - Department of Chemistry, California Institute of Technology, Pasadena, California 91125, United States

Hugo Leandri - Department of Environmental Science and Engineering, California Institute of Technology, Pasadena, California 91125, United States
Michael R. Hoffmann - Department of Environmental Science and Engineering, California Institute of Technology, Pasadena, California 91125, United States; (1) orcid.org/ 0000-0001-6495-1946

Complete contact information is available at: https://pubs.acs.org/10.1021/acsestengg.1c00240

\section{Author Contributions}

L.D., S.K., A.L., and H.L. carried out the experiments. L.D. and S.K. co-wrote the manuscript with support from A.L., C.C. and M.H. C.C. conceived the original idea and helped supervise the project. M.H. supervised the project.

\section{Notes}

The authors declare no competing financial interest.

\section{ACKNOWLEDGMENTS}

This work was supported, in whole or in part, by the Bill \& Melinda Gates Foundation (grant INV-003227). Under the grant conditions of the Foundation, a Creative Commons Attribution 4.0 Generic License has already been assigned to the Author Accepted Manuscript version that might arise from this submission. The authors would like to thank Nathan Dalleska, Director of the Resnick Water and Environment Laboratory for his help with TOC and TIC measurements.

\section{REFERENCES}

(1) Cayan, D. R.; Das, T.; Pierce, D. W.; Barnett, T. P.; Tyree, M.; Gershunov, A. Future dryness in the southwest US and the hydrology of the early 21 st century drought. Proc. Natl. Acad. Sci. U. S. A. 2010, 107 (50), 21271-21276.

(2) Sivakumar, B. Global climate change and its impacts on water resources planning and management: assessment and challenges. Stochastic Environmental Research and Risk Assessment 2011, 25 (4), $583-600$

(3) Ghernaout, D. Water Reuse (WR): The Ultimate and Vital Solution for Water Supply Issues. International Journal of Sustainable Development Research 2017, 3 (4), 36.

(4) Sahondo, T.; Hennessy, S.; Sindall, R. C.; Chaudhari, H.; Teleski, S.; Lynch, B. J.; Sellgren, K. L.; Stoner, B. R.; Grego, S.; Hawkins, B. T. Field testing of a household-scale onsite blackwater treatment system in South Africa. Sci. Total Environ. 2020, 703, 135469.

(5) Varigala, S. K.; Hegarty-Craver, M.; Krishnaswamy, S.; Madhavan, P.; Basil, M.; Rosario, P.; Raj, A.; Barani, V.; Cid, C. A.; Grego, S.; Luettgen, M. Field testing of an onsite sanitation system on apartment building blackwater using biological treatment and electrochemical disinfection. Environmental Science: Water Research \& Technology 2020, 6 (5), 1400-1411.

(6) Wu, T.; Englehardt, J. D. Peroxone mineralization of chemical oxygen demand for direct potable water reuse: Kinetics and process control. Water Res. 2015, 73, 362-372.

(7) Bruursema, T. The new NSF 350 and 350-1. Plumbing Systems \& Design Magazine 2011, 15.

(8) Li, F.; Wichmann, K.; Otterpohl, R. Review of the technological approaches for grey water treatment and reuses. Sci. Total Environ. 2009, 407 (11), 3439-3449.

(9) Reif, R.; Omil, F.; Lema, J. M. Removal of pharmaceuticals by membrane bioreactor (MBR) technology. In Comprehensive Analytical Chemistry; Elsevier: 2013; Vol. 62, pp 287-317.

(10) Weavers, L. K.; Malmstadt, N.; Hoffmann, M. R. Kinetics and mechanism of pentachlorophenol degradation by sonication, ozonation, and sonolytic ozonation. Environ. Sci. Technol. 2000, 34 (7), $1280-1285$

(11) Gassie, L. W.; Englehardt, J. D. Advanced oxidation and disinfection processes for onsite net-zero greywater reuse: A review. Water Res. 2017, 125, 384-399. 
(12) Wang, Y. The electro-peroxone technology as a promising advanced oxidation process for water and wastewater treatment. In Electro-Fenton Process; Springer, 2017; pp 57-84.

(13) International Organization for Standardization. Non-sewered sanitation systems - Prefabricated integrated treatment units General safety and performance requirements for design and testing; ISO 30500:2018.

(14) Sellers, R. M. Spectrophotometric determination of hydrogen peroxide using potassium titanium(IV) oxalate. Analyst 1980, 105 (1255), 950-954.

(15) Bisutti, I.; Hilke, I.; Raessler, M. Determination of total organic carbon - an overview of current methods. TrAC, Trends Anal. Chem. 2004, 23 (10), 716-726.

(16) Water Environmental Federation; American Public Health Association. Standard Methods for the Examination of Water and Wastewater; American Public Health Association (APHA): Washington, DC, 2005.

(17) Onsite Residential and Commercial Water Reuse Treatment Systems; NSF/ANSI 350, 2011.

(18) Eriksson, E.; Andersen, H. R.; Madsen, T. S.; Ledin, A. Greywater pollution variability and loadings. Ecological engineering 2009, 35 (5), 661-669.

(19) Amor, C.; Marchão, L.; Lucas, M. S.; Peres, J. A. Application of Advanced Oxidation Processes for the Treatment of Recalcitrant Agro-Industrial Wastewater: A Review. Water 2019, 11 (2), 205.

(20) Cohen, Y.; Kirchmann, H. Increasing the $\mathrm{pH}$ of wastewater to high levels with different gases-CO 2 stripping. Water, Air, Soil Pollut. 2004, 159 (1), 265-275.

(21) Moghadam, F. N.; Hamidmousavi, R. S.; Dashti, I.; Moghadm, M. N. Evaluating the efficiency of phosphorus removal in aqueous solutions by Fenton method. International Journal of Current Research 2016, 8 (12), 43662-43665.

(22) Kasak, K.; Karabelnik, K.; Kõiv, M.; Jenssen, P.; Mander, Ü. Phosphorus removal from greywater in an experimental hybrid compact filter system. WIT Trans. Ecol. Environ. 2011, 145, 649-657.

(23) Lin, S. H.; Chang, C. C. Treatment of landfill leachate by combined electro-Fenton oxidation and sequencing batch reactor method. Water Res. 2000, 34 (17), 4243-4249.

(24) Asada, T.; Ohkubo, T.; Kawata, K.; Oikawa, K. Ammonia adsorption on bamboo charcoal with acid treatment. J. Health Sci. 2006, 52 (5), 585-589.

(25) Pressley, T. A.; Bishop, D. F.; Roan, S. G. Ammonia-nitrogen removal by breakpoint chlorination. Environ. Sci. Technol. 1972, 6 (7), 622-628.

(26) Cho, K.; Hoffmann, M. R. Urea Degradation by Electrochemically Generated Reactive Chlorine Species: Products and Reaction Pathways. Environ. Sci. Technol. 2014, 48 (19), 11504-11511.

(27) Connick, R. E. The interaction of hydrogen peroxide and hypochlorous acid in acidic solutions containing chloride ion. J. Am. Chem. Soc. 1947, 69 (6), 1509-1514.

(28) Kovács, N.; Grozovski, V.; Moreno-García, P.; Broekmann, P.; Vesztergom, S. A Model for the Faradaic Efficiency of Base Metal Electrodeposition from Mildly Acidic Baths to Rotating Disk Electrodes. J. Electrochem. Soc. 2020, 167 (10), 102510.

(29) Mavrikis, S.; Perry, S. C.; Leung, P. K.; Wang, L.; Ponce de León, C. Recent Advances in Electrochemical Water Oxidation to Produce Hydrogen Peroxide: A Mechanistic Perspective. ACS Sustainable Chem. Eng. 2021, 9, 76-91.

(30) Christensen, H.; Sehested, K.; Corfitzen, H. Reactions of hydroxyl radicals with hydrogen peroxide at ambient and elevated temperatures. J. Phys. Chem. 1982, 86 (9), 1588-1590.

(31) Buxton, G. V.; Greenstock, C. L.; Helman, W. P.; Ross, A. B. Critical review of rate constants for reactions of hydrated electrons, hydrogen atoms and hydroxyl radicals $(\cdot \mathrm{OH} / \cdot \mathrm{O}$ - in aqueous solution. J. Phys. Chem. Ref. Data 1988, 17 (2), 513-886.

(32) Fischbacher, A.; von Sonntag, J.; von Sonntag, C.; Schmidt, T. C. The $\bullet \mathrm{OH}$ radical yield in the $\mathrm{H} 2 \mathrm{O} 2+\mathrm{O} 3$ (peroxone) reaction. Environ. Sci. Technol. 2013, 47 (17), 9959-9964.
(33) Puts, G. J.; Crouse, P.; Ameduri, B. M. Polytetrafluoroethylene: synthesis and characterization of the original extreme polymer. Chem. Rev. 2019, 119 (3), 1763-1805.

(34) Li, Y.; Zhang, Y.; Xia, G.; Zhan, J.; Yu, G.; Wang, Y. Evaluation of the technoeconomic feasibility of electrochemical hydrogen peroxide production for decentralized water treatment. Front. Environ. Sci. Eng. 2021, 15 (1), 1.

(35) Walter, C.; Kummer, K.; Vyalikh, D.; Brüser, V.; Quade, A.; Weltmann, K.-D. Using a Dual Plasma Process to Produce CobaltPolypyrrole Catalysts for the Oxygen Reduction Reaction in Fuel Cells: I. Characterization of the Catalytic Activity and Surface Structure. J. Electrochem. Soc. 2012, 159 (8), F494. 